\title{
Comparison of Two Estrus-Synchronization Protocols and Timed Artificial Insemination in Dairy Cattle
}

\author{
P. Melendez, ${ }^{\star 1}$ G. Gonzalez,† E. Aguilar,† O. Loera, † C. Risco, ${ }^{*}$ and L. F. Archbald ${ }^{\star}$ \\ ${ }^{*}$ College of Veterinary Medicine, University of Florida, Gainesville 32610 \\ †Zaragoza Hermanos Dairy Farm, Chihuahua, Mexico
}

\begin{abstract}
The objective of this study was to evaluate the effect of the Ovsynch protocol with and without exogenous progesterone on pregnancy rate $(\mathrm{PR})$ in cows in which estrous cycles were previously synchronized with 2 doses of $\mathrm{PGF}_{2 \alpha}$ and that were not detected in estrus during the presynchronization period. The study was conducted in Chihuahua, Mexico (8,650 Holstein milking cows; 305-d mature equivalent milk yield $=13,790$ $\mathrm{kg}$ ). On d 47 postpartum, estrous cycles in cows were synchronized by using 2 doses of $\mathrm{PGF}_{2 \alpha} 14 \mathrm{~d}$ apart. Any cow detected in estrus during this presynchronization period was inseminated. Cows not detected in estrus were selected at random and assigned to receive progesterone supplementation or to serve as controls. Controls $(\mathrm{n}=594)$ were subjected to the Ovsynch protocol and cows in the progesterone supplemented treatment $(\mathrm{n}=$ 594) were subjected to the Ovsynch protocol plus an intravaginal insert containing $1.9 \mathrm{~g}$ of progesterone inserted at the time of the first GnRH injection and removed $7 \mathrm{~d}$ later. Progesterone-supplemented cows had a greater PR (31.2\%) compared with controls (22.7\%). Plasma progesterone concentrations at artificial insemination (AI) were $<1 \mathrm{ng} / \mathrm{mL}$ and did not differ between treatments. At $14 \mathrm{~d}$ post-AI, however, more cows that received progesterone supplementation had concentrations of progesterone $>1 \mathrm{ng} / \mathrm{mL}$ compared with controls. It was concluded that after a presynchronization period, cows subjected to the Ovsynch program and supplemented with exogenous progesterone had a greater PR and greater concentrations of progesterone after AI than those subjected to the Ovsynch protocol and not supplemented with progesterone.
\end{abstract}

Key words: Ovsynch, progesterone, fertility, pregnancy rate

\section{INTRODUCTION}

Timed AI (TAI) and estrus-synchronization protocols have become a popular reproductive strategy to im-

Received February 6, 2006.

Accepted June 26, 2006.

${ }^{1}$ Corresponding author: melendezp@mail.vetmed.ufl.edu prove pregnancy rate $(\mathbf{P R})$ in modern dairy cattle operations (Pursley et al., 1995; Burke et al., 1996; Stevenson et al., 1999). The advantage of these protocols is that detection of estrus is not necessary. Therefore, TAI has become crucial in herds in which detection of estrus is difficult, especially in large dairy herds.

The Ovsynch protocol can be started at any time of the estrous cycle of the cow. It involves administration of 1 dose of $\mathrm{GnRH}$, followed in $7 \mathrm{~d}$ by $\mathrm{PGF}_{2 \alpha}$, and a second dose of GnRH $2 \mathrm{~d}$ after $\mathrm{PGF}_{2 \alpha}$, and subsequent TAI 12 to $24 \mathrm{~h}$ later. The protocol synchronizes ovarian follicular waves and time of ovulation (Pursley et al., 1995). Studies using the Ovsynch protocol have shown PR between 30 and 40\% (Pursley et al., 1995; Burke et al., 1996; Stevenson et al., 1999). It has been demonstrated that ovulation was synchronized more precisely and fertility was improved when the Ovsynch protocol was started between d 5 and 12 of the estrous cycle (Vasconcelos et al., 1999; Cartmill et al., 2001). Subsequently, it was shown that the administration of 2 doses of $\mathrm{PGF}_{2 \alpha}, 14 \mathrm{~d}$ apart (Presynch) placed a large proportion of cows between $\mathrm{d} 5$ and 12 of the estrous cycle when the Ovsynch program was started $12 \mathrm{~d}$ after the second dose of $\mathrm{PGF}_{2 \alpha}$ of this protocol (Moreira et al., 2001).

Other derivations of these original protocols have been developed during the last few years. When an intravaginal insert containing progesterone $\left(\mathbf{P}_{\mathbf{4}}\right)$ was administered for $7 \mathrm{~d}$ between the first dose of $\mathrm{GnRH}$ and the administration of $\mathrm{PGF}_{2 \alpha}$ of the Ovsynch protocol, conception rate to TAI was improved (El-Zarkouny et al., 2004; Ambrose et al., 2005; Stevenson et al., 2006). A reproductive protocol using Presynch combined with detected estrus and subsequent Ovsynch with $\mathrm{P}_{4}$ supplementation for cows not identified in estrus has not been reported previously.

The hypothesis of this study was that supplementing cows with $\mathrm{P}_{4}$ via an intravaginal insert during the Ovsynch protocol would improve PR in cows not previously observed in estrus during a presynchronization period. The objective of this study was to evaluate, in a large dairy herd in Mexico, the effect of the Ovsynch protocol with exogenous $\mathrm{P}_{4}$ on $\mathrm{PR}$ in cows that were previously 
subjected to the Presynch protocol, but were not observed in estrus during the presynchronization period.

\section{MATERIALS AND METHODS}

\section{Cows and Herd Management}

The study was conducted in a large dairy herd in Chihuahua, Mexico, between January and December 2005. This herd consisted of 8,650 milking cows with a mature equivalent $305-\mathrm{d}$ milk yield of $13,790 \mathrm{~kg}$. Lactating cows were housed in dry lots, milked, and fed a TMR 4 times daily to meet or exceed the nutritional requirements of NRC (2001). Cows were dried off between 50 and $70 \mathrm{~d}$ before expected parturition and maintained in a dry lot (far-off cows) until $21 \mathrm{~d}$ before expected parturition. Prepartum transition (close-up) cows ( $21 \mathrm{~d}$ before expected parturition) were housed in a dry lot with adequate feed bunk space and shade.

Within $12 \mathrm{~h}$ postpartum, cows were routinely evaluated. This evaluation consisted of BCS (scale of 1 to 5) and mammary gland evaluation for clinical mastitis (strip cup). Determination of retained fetal membranes was conducted at $24 \mathrm{~h}$ postpartum. If fetal membranes were retained and fever occurred $\left(>39.5^{\circ} \mathrm{C}\right)$, cows were treated with a systemic antibiotic daily for $5 \mathrm{~d}$ (oxytetracycline i.v., $15 \mathrm{mg} / \mathrm{kg}$ of BW). After processing, cows were moved to a postpartum lot for approximately 21 d. At 60 DIM cows were given $500 \mathrm{mg}$ of bST s.c. every $11 \mathrm{~d}$ until 200 DIM. The voluntary waiting period was $47 \mathrm{~d}$. On d 47, cows were subjected to a presynchronization protocol using 2 doses of $\mathrm{PGF}_{2 \alpha} 14 \mathrm{~d}$ apart (Presynch; Moreira et al., 2001). Any cow detected in estrus after administration of either of the 2 doses of $\mathrm{PGF}_{2 \alpha}$ was inseminated at estrus according to the a.m.-p.m. rule. Cows not detected in estrus during that period were subjected $12 \mathrm{~d}$ later to the Ovsynch protocol (Pursley et al., 1995). Pregnancy rate at this synchronized ovulation was reported to be $19.5 \%$ in a previous study in the same dairy herd (Melendez et al., 2006).

\section{Experimental Protocol}

Controls were those cows subjected to the Ovsynch protocol that had not been previously identified in estrus during the presynchronization period $($ Pre + Ov). Treatment cows were subjected to the Ovsynch protocol and also received a $\mathrm{P}_{4}(1.9 \mathrm{~g})$ intravaginal insert given at the time of the first $\mathrm{GnRH}$ and removed $7 \mathrm{~d}$ later $\left(\right.$ Pre $\left.+\mathbf{O v}+\mathbf{P}_{4}\right)$. To detect an increase in PR from $20 \%$ to $27 \%$ (95\% confidence; $80 \%$ power), a sample size of 452 cows/treatment was required (Win Episcope, 2000).

At d 73 postpartum, Pre + Ov cows $(\mathrm{n}=594 ; 203$ primiparous and 391 multiparous cows) received a dose of $\mathrm{GnRH}$ (100 $\mu \mathrm{g}$ of gonadorelin, i.m.), a dose of $\mathrm{PGF}_{2 \alpha}$
(500 $\mu \mathrm{g}$ of cloprostenol, i.m.) $7 \mathrm{~d}$ later, a second dose of GnRH (100 $\mu \mathrm{g}$ of gonadorelin, i.m.) $2 \mathrm{~d}$ later, and TAI 16 to $24 \mathrm{~h}$ later.

Cows from the Pre $+\mathrm{Ov}+\mathrm{P}_{4}$ treatment $(\mathrm{n}=594 ; 203$ primiparous and 391 multiparous cows) were matched randomly by parity using frequency matching based on farm records to obtain a similar number of primiparous and multiparous cows per treatment. These cows also started the Ovsynch protocol at $73 \mathrm{~d}$ postpartum, and a $\mathrm{P}_{4}$-releasing intravaginal insert $\left(1.9 \mathrm{~g}\right.$ of $\left.\mathrm{P}_{4}\right)$ was inserted at the time of the first $\mathrm{GnRH}$ dose and removed $7 \mathrm{~d}$ later. Cows also were given a dose of $\mathrm{PGF}_{2 \alpha}$ when the intravaginal insert was removed. Cows in both treatments were fed the same diet and were subjected to the same environmental and management conditions. Treatments were blind to inseminators.

The main outcome of interest was the PR at the synchronized AI, defined as cows that conceived at the synchronized AI (diagnosed by palpation per rectum between 42 and $48 \mathrm{~d}$ after TAI) divided by the total number of cows treated and inseminated.

\section{Progesterone Assay}

Expecting a difference in plasma $\mathrm{P}_{4}$ concentrations of $0.2 \pm 0.4 \mathrm{ng} / \mathrm{mL}$ at breeding and at $14 \mathrm{~d}$ postbreeding (95\% confidence and $80 \%$ power), 52 cows per treatment were needed (Win Episcope, 2000). Fifty-five cows per treatment were selected randomly to measure $\mathrm{P}_{4}$ at TAI and at $14 \mathrm{~d}$ later. A blood sample was collected at the time of TAI and $14 \mathrm{~d}$ later from the coccygeal vessels using an evacuated blood-collection tube. Samples were centrifuged at $2,500 \times g$ for $30 \mathrm{~min}$ and stored at $-20^{\circ} \mathrm{C}$ until analysis was performed. Subsequently, $\mathrm{P}_{4}$ was determined using a solid-phase, no-extraction radioimmunoassay. The intra- and interassay CV coefficients of variation were 4.8 and $6.1 \%$, respectively. The proportion of cows within treatment having $\mathrm{P}_{4}<1 \mathrm{ng} /$ $\mathrm{mL}$ was calculated at $\mathrm{d} 0$ and 14 after TAI. In addition, the proportion of cows within treatment with different combinations of $\mathrm{P}_{4}$ at $\mathrm{d} 0$ and 14 was obtained. A concentration of $\mathrm{P}_{4}<1 \mathrm{ng} / \mathrm{mL}$ was considered to be low and $\mathrm{P}_{4}$ $\geq 1 \mathrm{ng} / \mathrm{mL}$ was considered to be high. Possible combinations for $\mathrm{d} 0$ and 14, respectively, were high-high, highlow, low-high, and low-low.

\section{Statistical Analysis}

A multivariable logistic regression model correcting for potential confounders was conducted to test the main effect of treatment. Explanatory variables (potential confounders) were parity (primiparous vs. multiparous), dystocia (yes vs. no), retained fetal membranes (yes vs. no), breeding season (summer, fall, winter, and 
spring) and inseminator. A backward elimination procedure with an inclusion criterion of $P \leq 0.05$ was conducted. Treatment was forced to remain in the final model. Adjusted odds ratios and 95\% confidence intervals (CI) were reported. Variables were considered significant at $P \leq 0.05$. Statistical analyses were conducted by using SAS (Version 9.1; SAS Institute, 2003).

The logistic model was defined as follows:

$$
\begin{aligned}
\log (\pi / 1-\pi) & =\alpha+\beta_{1} \mathrm{X}_{1}+\beta_{2} \mathrm{X}_{2}+\beta_{3} \mathrm{X}_{3}+\beta_{4} \mathrm{X}_{4} \\
+ & \beta_{5} \mathrm{X}_{5}+\beta_{6} \mathrm{X}_{6}+\beta_{7} \mathrm{X}_{7},
\end{aligned}
$$

where $\pi / 1-\pi=$ odds of the event (conception at synchronized service; yes vs. no); $\alpha=$ intercept; $\beta_{1}=$ parameter of $\mathrm{X}_{1} ; \mathrm{X}_{1}=$ effect of treatment; $\beta_{2}=$ parameter of $\mathrm{X}_{2}$; $\mathrm{X}_{2}=$ effect of parity; $\beta_{3}=$ parameter of $\mathrm{X}_{3} ; \mathrm{X}_{3}=$ effect of season; $\beta_{4}=$ parameter of $\mathrm{X}_{4} ; \mathrm{X}_{4}=$ effect of inseminator; $\beta_{5}=$ parameter of $\mathrm{X}_{5} ; \mathrm{X}_{5}=$ effect of dystocia; $\beta_{6}=$ parameter of $\mathrm{X}_{6} ; \mathrm{X}_{6}=$ effect of retained fetal membranes; $\beta_{7}=$ parameter of $\mathrm{X}_{7}$; and $\mathrm{X}_{7}=$ effect of 2 -way interactions.

Statistical analysis of $\mathrm{P}_{4}$ concentrations was conducted by using a mixed model procedure with cow nested within treatment as a random effect. The model considered parity, breeding season, dystocia, and retained fetal membranes as explanatory variables. Mixed model for $\mathrm{P}_{4}$ was defined as follows:

$$
\mathrm{y}=\alpha+\beta_{1} \mathrm{X}_{1}+\beta_{2} \mathrm{X}_{2}+\beta_{3} \mathrm{X}_{3}+\beta_{4} \mathrm{X}_{4}+\beta_{5} \mathrm{X}_{5}+\beta_{6} \mathrm{X}_{6},
$$

where $\mathrm{y}=$ progesterone concentrations (at TAI and 14 $\mathrm{d}$ later); $\alpha=$ intercept; $\beta_{1}=$ parameter of $\mathrm{X}_{1} ; \mathrm{X}_{1}=$ effect of treatment; $\beta_{2}=$ parameter of $\mathrm{X}_{2} ; \mathrm{X}_{2}=$ effect of parity; $\beta_{3}=$ parameter of $\mathrm{X}_{3} ; \mathrm{X}_{3}=$ effect of season; $\beta_{4}=$ parameter of $\mathrm{X}_{4} ; \mathrm{X}_{4}=$ effect of dystocia; $\beta_{5}=$ parameter of $\mathrm{X}_{5}$; $\mathrm{X}_{5}=$ effect of retained fetal membranes; $\beta_{6}=$ parameter of $\mathrm{X}_{6}$; and $\mathrm{X}_{6}=$ effect of 2 -way interactions.

\section{RESULTS}

During 2005, 5,162 cows were subjected to the Presynch protocol. From this number, 3,974 cows were identified in estrus and bred after detected estrus. The remaining 1,188 cows not observed in estrus and not inseminated were assigned randomly to 2 treatments. From the 1,188 cows that started the study, 8 cows from the Pre $+\mathrm{Ov}+\mathrm{P}_{4}$ treatment and 5 cows from the Pre + Ov treatment were not included in the final analysis because of missing data. Therefore, only data from 586 cows from the Pre $+\mathrm{Ov}+\mathrm{P}_{4}$ treatment (203 primiparous and 383 multiparous cows) and 589 cows from the Pre + Ov treatment (203 primiparous and 391 multiparous cows) were considered for the statistical

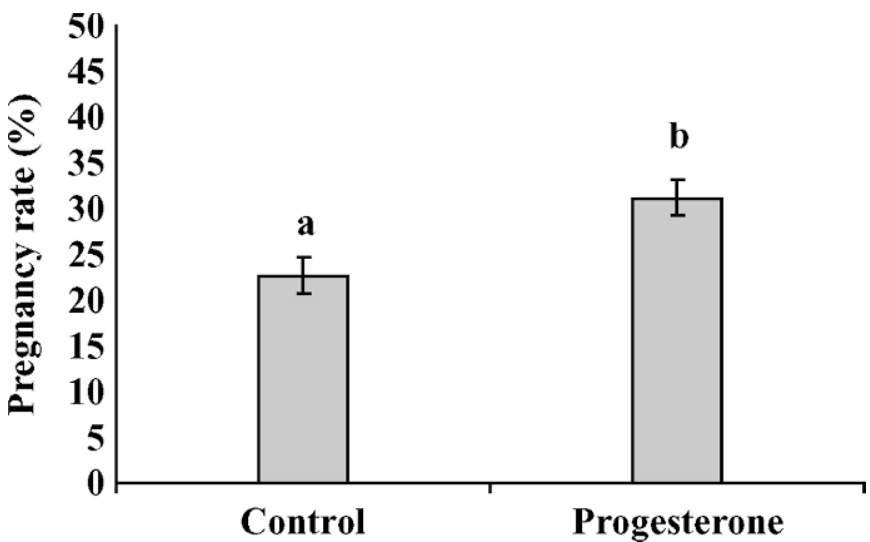

Figure 1. Pregnancy rate of cows supplemented with progesterone $\left(\mathrm{P}_{4}\right)$ differed $(P \leq 0.05)$ from control. Control: Ovsynch starting at 73 DIM (Pre + Ov). Progesterone: Ovsynch starting at 73 DIM plus exogenous intravaginal $\mathrm{P}_{4}$ insert $(1.9 \mathrm{~g}$ ) for $7 \mathrm{~d}$ between first $\mathrm{GnRH}$ and $\mathrm{PGF}_{2 \alpha}$ injection of the Ovsynch protocol $\left(\mathrm{Pre}+\mathrm{Ov}+\mathrm{P}_{4}\right)$. Estrous cycles in all cows were presynchronized with 2 doses of $\mathrm{PGF}_{2 \alpha}$ (Presynch) and only cows not previously inseminated after Presynch injections were assigned to treatments.

analysis. Pregnancy rates which differed $(P \leq 0.05)$ between Pre $+\mathrm{Ov}+\mathrm{P}_{4}$ and Pre + Ov treatments, were 31.2 and $22.7 \%$, respectively (Figure 1 ).

After the backward elimination procedure, there were no significant 2-way interaction terms in the final model. Because parity, breeding season, retained fetal membranes, and inseminator also were not significant variables, they were eliminated during the backward selection process. Only the effects of treatment and dystocia were significant terms and remained in the final model. The adjusted effect of treatment was that cows receiving supplemental $\mathrm{P}_{4}$ during the Ovsynch were 1.52 times more ( $95 \% \mathrm{CI}=1.17$ to 1.97 ) likely to become pregnant than cows from the Pre + Ov treatment. In addition, cows that did not experience dystocia were 1.59 times more (95\% $\mathrm{CI}=1.05$ to 2.42 ) likely to become pregnant than cows that experienced dystocia at parturition (Table 1).

Concentrations of plasma $\mathrm{P}_{4}$ are shown in Figure 2. At TAI, $\mathrm{P}_{4}$ was below $1 \mathrm{ng} / \mathrm{mL}$ and did not differ between Pre $+\mathrm{Ov}+\mathrm{P}_{4}(0.76 \pm 0.3 \mathrm{ng} / \mathrm{mL})$ and Pre + Ov treatments $(0.68 \pm 0.2 \mathrm{ng} / \mathrm{mL})$. The proportion of cows having $\mathrm{P}_{4}<1 \mathrm{ng} / \mathrm{mL}$ (low) was $83.6 \%$ (46/55) and 80\% (44/55) for Pre $+\mathrm{Ov}+\mathrm{P}_{4}$ and Pre + Ov treatments, respectively. At $14 \mathrm{~d}$ after TAI, $\mathrm{P}_{4}$ was $>1 \mathrm{ng} / \mathrm{mL}$ and differed between groups in pregnant and nonpregnant cows. The proportion of cows with $\mathrm{P}_{4}<1 \mathrm{ng} / \mathrm{mL}$ was $5.46 \%(3 / 55)$ and $10.9 \%(6 / 55)$ for Pre $+\mathrm{Ov}+\mathrm{P}_{4}$ and Pre + Ov treatments, respectively. In addition, proportions of cows having different combinations of $\mathrm{P}_{4}$ at $\mathrm{d} 0$ and 14 after TAI for Pre $+\mathrm{Ov}+\mathrm{P}_{4}$ and Pre $+\mathrm{Ov}$ treatments were as follows: high-high (14.7 and 12.2\%); high-low (0 and 6.1\%); 
Table 1. Summary of final logistic regression model for pregnancy rate in cows subjected to Ovsynch and treated with progesterone $\left(\mathrm{P}_{4}\right)$

\begin{tabular}{|c|c|c|c|}
\hline Item & $\begin{array}{l}\text { Odds } \\
\text { ratio } \\
\text { (OR) }\end{array}$ & $\begin{array}{l}95 \% \mathrm{CI}^{1} \\
\text { OR }\end{array}$ & $P$-values \\
\hline Group $\left(\mathrm{P}_{4}\right.$ vs. no $\left.\mathrm{P}_{4}\right)$ & 1.52 & $1.07-1.97$ & 0.0015 \\
\hline Parturition (normal vs. assisted) & 1.59 & $1.05-2.42$ & 0.028 \\
\hline
\end{tabular}

${ }^{1} \mathrm{CI}=$ Confidence interval.

low-high (80.9 and 75.5\%); and low-low (4.4 and 6.1\%), respectively. The 2-way interactions, retained fetal membranes, dystocia, or season failed to account significantly for variation in concentrations of $\mathrm{P}_{4}$ at TAI or $14 \mathrm{~d}$ later.

\section{DISCUSSION}

The present study was conducted to maximize PR of cows that were subjected to a presynchronization protocol of 2 doses of $\mathrm{PGF}_{2 \alpha}$ ( $14 \mathrm{~d}$ apart) but not identified in estrus after either of the 2 doses of $\mathrm{PGF}_{2 \alpha}$. An important aspect of this study was the application of our treatments to a large number of cows that were managed under the same conditions during the entire experimental period. Therefore, a significant source of variation was the use of exogenous $\mathrm{P}_{4}$ in the Pre $+\mathrm{Ov}$ $+\mathrm{P}_{4}$ treatment.

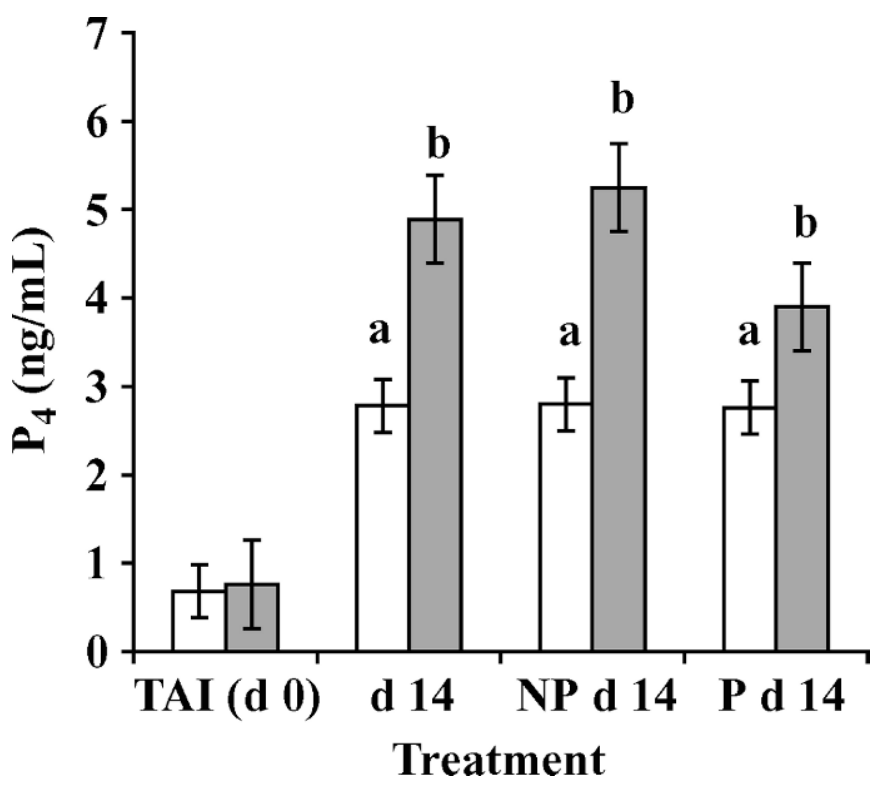

Figure 2. Least squares means \pm SEM of plasma progesterone $\left(\mathrm{P}_{4}\right)$ concentrations in cows with (solid bars) and without (open bars) $\mathrm{P}_{4}$ supplementation at TAI and at $14 \mathrm{~d}$ later within pregnancy status. TAI $(\mathrm{d} 0)=$ all cows $(\mathrm{n}=110) ; \mathrm{d} 14=$ all cows 14 d after TAI $(\mathrm{n}=$ 110); NP d 14 = all nonpregnant cows on d $14(\mathrm{n}=77)$; and P d $14=$ all pregnant cows on d $14(\mathrm{n}=33)$. Bars having different letters within category differ $(P \leq 0.05)$.
Pregnancy rate was significantly greater in cows receiving $\mathrm{P}_{4}$ than in cows not receiving $\mathrm{P}_{4}$. A few studies have investigated similar reproductive protocols and have found comparable results in dairy cattle (Cavestany et al., 2003; El-Zarkouny et al., 2004; Stevenson et al., 2006). Nevertheless, in those 3 studies, cows subjected to the Ovsynch protocol with and without $\mathrm{P}_{4}$ were not exposed to presynchronizing of estrous cycles (2 doses of $\mathrm{PGF}_{2 \alpha}$ ) or, inseminated after estrus before starting the Ovsynch protocol as in the present study. Only Experiment 2 of 1 study (El-Zarkouny et al., 2004) considered a similar protocol similar to the present investigation. Detection of estrus and AI was not part of their protocol during the presynchronization period. Pregnancy rate was improved in cows receiving $\mathrm{P}_{4}$ only in Experiment 1 of El-Zarkouny et al. (2004) study (45.1 vs. $20.9 \%$ ). This was dependent on the cyclic status of cows because the improvement of PR was observed only in cows classified as anestrus. In Experiment 2 of the El-Zarkouny et al. (2004) study, the proportion of cows in early diestrus at the onset of the Ovsynch protocol was increased for cows that were subjected previously to the Presynch protocol. In addition, these cows had a greater PR than cows not presynchronized. No interaction between presynchronization and supplementation of $\mathrm{P}_{4}$ was found; however, results must be interpreted with caution because PR almost doubled in cows that were classified as anestrus, were presynchronized, and received $1.9 \mathrm{~g}$ of $\mathrm{P}_{4}$ compared to similar cows receiving no $\mathrm{P}_{4}$ (50 vs. $27.3 \%$ ). Differences were not significant, partly because of lack of power or small sample size to demonstrate statistical differences when cows are subcategorized based on serum $\mathrm{P}_{4}$.

Because cows assigned to the current study were subjected to detected estrus and AI but were not identified in estrus during the presynchronization period, this might suggest that a large proportion of cows starting the synchronization program were not cycling. Mean $\mathrm{P}_{4}$ at TAI was $<1 \mathrm{ng} / \mathrm{mL}$ and did not differ between treatments. In addition, proportions of cows having $\mathrm{P}_{4}$ $<1 \mathrm{ng} / \mathrm{mL}$ did not differ between treatments (83.6 vs. $80 \%$ for Pre $+\mathrm{Ov}+\mathrm{P}_{4}$ and Pre + Ov treatments, respectively). This suggests that a large proportion of cows were not in diestrus, and may imply that cows were either adequately synchronized in both treatments, were anestrous, or both.

The proportion of cows having $\mathrm{P}_{4}>1 \mathrm{ng} / \mathrm{mL}$ at $14 \mathrm{~d}$ after TAI in Pre $+\mathrm{Ov}+\mathrm{P}_{4}$ and Pre + Ov treatment was 94.5 and $89.1 \%$ respectively, suggesting that a large proportion of cows in both treatments were cycling; only 4.4 and $6.1 \%$ of cows had $\mathrm{P}_{4}<1 \mathrm{ng} / \mathrm{mL}$ at TAI and at $14 \mathrm{~d}$ later (low-low). These percentages are slightly greater but similar to those reported by Galvão et al. (2004). Nevertheless, our findings indicate that a large 
proportion of cows were cycling, although the cycling status of cows at the onset of treatments is unknown. Consequently, based on the present results, we can only suggest that a similar proportion of cows were cyclic after the Ovsynch with or without $\mathrm{P}_{4}$. As a result, improved fertility using exogenous $\mathrm{P}_{4}$ during the Ovsynch protocol might be explained because of greater concentrations of $\mathrm{P}_{4}$ before TAI determineing better synchronization of ovulation than would no supplementation with $\mathrm{P}_{4}$ (Wehrman et al., 1993; Smith and Stevenson, 1995; Stevenson et al., 2006). In addition, reduced concentrations of $\mathrm{PGF}_{2 \alpha}$ have been reported for cows during the estrous cycle subsequent to a cycle supplemented with an intravaginal $\mathrm{P}_{4}$ device, which may be related to better luteal maintenance and improved fertility in dairy cows (Shaham-Albalancy et al., 2001).

Although $\mathrm{GnRH}$ without $\mathrm{P}_{4}$ (Pre + Ov treatment) may result in the release of a preovulatory surge of $\mathrm{LH}$, a small dominant follicle may have limited LH receptors and may contain fewer granulosa cells than a normal, LH-dependent follicle (Macmillan et al., 2003). Consequently, exposure of noncycling cows to $\mathrm{P}_{4}$ could stimulate the hypothalamic-pituitary axis to trigger mechanisms that facilitate ovulation (Rhodes et al., 2003). In contrast to the present study, Experiment 2 of ElZarkouny et al. (2004), which compared anestrous cows, based on low $\mathrm{P}_{4}$ at $\mathrm{d}-10$ and -3 before TAI, that were exposed to 2 presynchronization doses of $\mathrm{PGF}_{2 \alpha}$, subjected to Ovsynch, and supplemented with $(\mathrm{n}=6)$ and without $\mathrm{P}_{4}(\mathrm{n}=11)$, demonstrated no differences in $\mathrm{PR}$ (50.0 vs. $27.3 \%$, respectively). Small numbers of cows per treatment, however, were not sufficient for detecting statistical differences.

The greater fertility of cows without than with dystocia reinforces the importance of having a consistent nutrition program during lactation and during the dry period to prevent obese cows and maintain a good transition dairy cow management program to prevent health disorders (NRC, 2001). Cows having dystocia are more likely to develop retained fetal membranes, metritis, and other calving-related disorders (Correa et al., 1993). Consequently, cows experiencing more periparturient diseases have reduced fertility (Gröhn et al., 2003).

In the present study, cows treated with $\mathrm{P}_{4}$ before TAI had greater concentrations of plasma $\mathrm{P}_{4} 14 \mathrm{~d}$ after TAI compared with cows subjected to Ovsynch without $\mathrm{P}_{4}$ supplementation. A normal luteal phase or greater $\mathrm{P}_{4}$ after $\mathrm{AI}$ are consistently associated with better fertility (Thatcher et al., 2002; Spencer et al., 2004; Moore et al., 2005). The fact that Ovsynch protocol supplemented with $\mathrm{P}_{4}$ during the first $7 \mathrm{~d}$ of the synchronization protocol induced greater $\mathrm{P}_{4}$ after ovulation may indicate that this response resulted from formation of a larger follicle before ovulation and a larger and a more active corpus luteum after ovulation. Indeed, diameter of the preovulatory follicle $24 \mathrm{~h}$ after $\mathrm{PGF}_{2 \alpha}$ administration has been reported to be greater in cows subjected to Ovsynch and treated with $\mathrm{P}_{4}$ compared with cows only subjected to the Ovsynch protocol $(14.6 \pm 0.4$ vs. $13.1 \pm 0.4 \mathrm{~mm}$, respectively; Stevenson et al., 2004). Nevertheless, in a study using a similar protocol, but with estradiol cypionate instead of $\mathrm{GnRH}, 24 \mathrm{~h}$ after the $\mathrm{PGF}_{2 \alpha}$ injection and a $\mathrm{P}_{4}$ insert removal, showed no differences in follicle sizes at ovulation (Galvão et al., 2004). Perhaps another possible explanation for improved fertility and greater $\mathrm{P}_{4}$ in the Pre $+\mathrm{Ov}+\mathrm{P}_{4}$ treatment than in the Pre + Ov treatment might be that $\mathrm{P}_{4}$ supplementation may induce more synchronized ovulation and normal luteal phases (Stevenson et al., 2006). Indeed, although the differences were not significant, the proportion of cows having $\mathrm{P}_{4}<1 \mathrm{ng} / \mathrm{mL}$ for the Pre + Ov treatment (10.9\%) was twice that observed for cows receiving supplemental $\mathrm{P}_{4}(5.5 \%)$.

Interestingly, among open cows, treatment with $\mathrm{P}_{4}$ significantly increased plasma $\mathrm{P}_{4}$ compared with cows without $\mathrm{P}_{4}$. This finding opens a debate regarding $\mathrm{P}_{4}$ supplementation either before or after AI to improve fertility in dairy cattle. Indeed, it has been reported that high $\mathrm{P}_{4}$ decreased $\mathrm{PR}$ in cows treated either with equine chorionic gonadotropin (Nogueira et al., 2004) or 2 injections of $\mathrm{GnRH}$ at $\mathrm{d} 5$ and 15 postbreeding (Bartolome et al., 2005), intended to increase $\mathrm{P}_{4}$ from the corpus luteum.

\section{CONCLUSIONS}

From the results of this study, it was concluded that cows not detected in estrus after presynchronization of estrous cycles by $\mathrm{PGF}_{2 \alpha}$ and subjected to the Ovsynch protocol starting on d 73 postpartum had greater PR when supplemented with exogenous $\mathrm{P}_{4}$ during the Ovsynch protocol.

\section{ACKNOWLEDGMENTS}

We thank the Zaragoza Hermanos Dairy Farm, Chihuahua, Mexico, for funding this study.

\section{REFERENCES}

Ambrose, J. D., J. P. Kastelic, R. Rajamahendran, M. Aali, and N. Dinn. 2005. Progesterone (CIDR)-based timed AI protocols using GnRH, porcine LH or estradiol cypionate for dairy heifers: Ovarian and endocrine responses and pregnancy rates. Theriogenology 64:1457-1474.

Bartolome, J. A., P. Melendez, D. Kelbert, K. Swift, J. McHale, J. Hernandez, F. Silvestre, C. A. Risco, A. C. M. Arteche, W. W. Thatcher, and L. F. Archbald. 2005. Strategic use of gonadotrophin-realising hormone $(\mathrm{GnRH})$ to increase pregnancy rate and reduce pregnancy loss in lactating dairy cows subjected to syn- 
chronization of ovulation and timed insemination. Theriogenology 63:1026-1037.

Burke, J. M., R. L. de La Sota, C. A. Risco, C. R. Staples, E. J. P. Schmitt, and W. W. Thatcher. 1996. Evaluation of timed insemination using a gonadotropin-releasing hormone agonist in lactating dairy cows. J. Dairy Sci. 79:1385-1393.

Cartmill, J. A., S. Z. El-Zarkouny, B. A. Hensley, G. C. Lamb, and J. S. Stevenson. 2001. Stage of cycle, incidence, and timing of ovulation, and pregnancy rates in dairy cattle after three timed breeding protocols. J. Dairy Sci. 84:1051-1059.

Cavestany, D., J. Cibils, A. Freire, A. Sastre, and J. S. Stevenson. 2003. Evaluation of two different oestrus-synchronization methods with timed artificial insemination and resynchronization of returns to oestrus in lactating Holstein cows. Anim. Reprod. Sci. 77:141-155.

Correa, M. T., H. Erb, and J. Scarlett. 1993. Path analysis for seven postpartum disorders of Holstein cows. J. Dairy Sci. 76:13051312.

El-Zarkouny, S. Z., J. A. Cartmill, B. A. Hensley, and J. S. Stevenson. 2004. Pregnancy in dairy cows after synchronized ovulation regimens with or without presynchronization and progesterone. J. Dairy Sci. 87:1024-1037.

Galvão, K. N., J. E. P. Santos, S. O. Juchem, R. L. A. Cerri, A. C. Coscioni, and M. Villaseñor. 2004. Effect of addition of a progesterone intravaginal insert to a timed insemination protocol using estradiol cypionate on ovulation rate, pregnancy rate, and late embryonic loss in lactating dairy cows. J. Anim. Sci. 82:35083517.

Gröhn, Y. T., P. J. Rajala-Schultz, H. G. Allore, M. A. DeLorenzo, J. A. Hertl, and D. T. Galligan. 2003. Optimizing replacement of dairy cows: modeling the effects of diseases. Prev. Vet. Med. 61:27-43.

Macmillan, K. L., B. V. E. Segwagwe, and C. S. Pino. 2003. Associations between the manipulation of patterns of follicular development and fertility in cattle. Anim. Reprod. Sci. 78:327-344.

Melendez, P., G. Gonzalez, M. Benzaquen, C. Risco, and L. Archbald. 2006. The effect of a monensin controlled-release capsule on the incidence of retained fetal membranes, milk yield and reproductive responses in Holstein cows. Theriogenology 66:234-241.

Moore, D. A., M. W. Overton, R. C. Chebel, M. L. Truscott, and R. H. BonDurant. 2005. Evaluation of factors that affect embryonic loss in dairy cattle. J. Am. Vet. Med. Assoc. 226:1112-1118.

Moreira, F., C. Orlandi, C. A. Risco, R. Mattos, F. Lopes, and W. W. Thatcher. 2001. Effect of presynchronization and bovine somatotropin on pregnancy rates to a time artificial insemination protocol in lactating dairy cows. J. Dairy Sci. 84:1646-1659.

NRC. 2001. Nutrient Requirements of Dairy Cattle. 7th rev. ed. Natl. Acad. Sci. Washington, DC.

Nogueira, M. F. G., D. S. Melo, L. M. Carvalho, E. J. Fuck, L. A. Trinca, and C. M. Barros. 2004. Do high progesterone concentrations decrease pregnancy rates in embryo recipients synchronized with $\mathrm{PGF}_{2 \alpha}$ and eCG? Theriogenology 61:1283-1290.

Pursley, J. R., M. O. Mee, and M. C. Wiltbank. 1995. Synchronization of ovulation in dairy cows using $\mathrm{PGF}_{2 \alpha}$ and $\mathrm{GnRH}$. Theriogenology 44:915-923.

Rhodes, F. M., S. M. McDougall, C. R. Burke, G. A. Verkerk, and K. L. Macmillan. 2003. Treatment of cows with an extended postpartum anestrous interval. J. Dairy Sci. 86:1876-1894.

SAS Institute. 2003. SAS/STAT Software: Change and enhancements through release 9.1 for Windows. SAS Inst. Inc, Cary, NC.

Shaham-Albalancy, A., Y. Folman, M. Kaim, M. Rosenberg, and D. Wolfenson. 2001. Delayed effect of low progesterone concentrations on bovine uterine $\mathrm{PGF}_{2 \alpha}$ secretion in the subsequent oestrous cycle. Reproduction 122:642-648.

Smith, M. W., and J. S. Stevenson. 1995. Fate of the dominant follicle, embryonal survival, and pregnancy rates in dairy cattle treated with prostaglandin $\mathrm{F}_{2 \alpha}$ and progestins in the absence or presence of a functional corpus luteum. J. Anim. Sci. 73:3743-3751.

Spencer, T. E., R. C. Burghardt, G. A. Johnson, and F. W. Bazer. 2004. Conceptus signals for establishment and maintenance of pregnancy. Anim. Reprod. Sci. 82-83:537-550.

Stevenson, J. S., J. R. Pursley, H. A. Garverick, P. M. Fricke, D. J. Kesler, J. S. Ottobre, and M. C. Wiltbank. 2006. Treatment of cycling and noncycling lactating dairy cows with progesterone during Ovsynch. J. Dairy Sci. 89:2567-2578.

Stevenson, J. S., S. M. Tiffany, and M. C. Lucy. 2004. Use of estradiol cypionate as a substitute for $\mathrm{GnRH}$ in protocols for synchronizing ovulation in dairy cattle. J. Dairy Sci. 87:3298-3305.

Stevenson, J. S., Y. Kobayashi, and K. E. Thompson. 1999. Reproductive performance of dairy cows in various programmed breeding systems including Ovsynch and combination of gonadotropin-releasing hormone and prostaglandin $\mathrm{F}_{2 \alpha}$. J. Dairy Sci. 82:506-515.

Thatcher, W. W., F. Moreira, S. M. Pancarci, J. A. Bartolome, and J. E. P. Santos. 2002. Strategies to optimize reproductive efficiency by regulation of ovarian function. Domest. Anim. Endocrinol. 23:243-254.

Vasconcelos, J. L., M. R. W. Silcox, G. J. M. Rosa, J. R. Pursley, and M. C. Wiltbank. 1999. Synchronization rate, size of the ovulatory follicle, and pregnancy rate alter synchronization of ovulation beginning on different days of the estrous cycle in lactating dairy cows. Theriogenology 52:1067-1078.

Wehrman, M. E., M. S. Roberson, A. S. Cupp, F. N. Kojima, T. T. Stumpf, L. A. Werth, M. W. Wolfe, R. J. Kittok, and J. E. Kinder. 1993. Increasing exogenous progesterone during synchronization of estrus decreases endogenous estradiol-17 $\beta$ and increases conception in cows. Biol. Reprod. 49:214-220.

Win Episcope 2000. Win Episcope 2.0: Software for quantitative veterinary epidemiology. Facultad de Veterinaria, Zaragoza, Spain; Agricultural University Wageningen, Netherlands; University of Utrecht, Netherlands; University of Edinburgh, United Kingdom. Borland Delphi@ 1.0. 